\title{
Specifics of developing the Institution of Public Service: International Experience and its application in Russia
}

\section{Características del desarrollo de la Institución de Servicio Público: Experiencia Internacional y su aplicación en Rusia}

\author{
DOI: https://doi.org/10.17981/juridcuc.17.1.2021.09
}

Fecha de Recepción: 2020/04/06 Fecha de Aceptación: 2020/10/27

\author{
Alexander Georgievich Gurinovich \\ Moscow State Institute of International Relations (MGIMO University). Moscow (Russian Federation) \\ gurinovich.AG@yandex.ru
}

\begin{abstract}
Natalya Ivanovna Petrykina 우
Moscow State Institute of International Relations (MGIMO University). Moscow (Russian Federation) npetrykina@yandex.ru
\end{abstract}

Para citar este artículo:

Gurinovich, A. \& Petrykina, N. (2021). Specifics of developing the Institution of Public Service: International Experience and its application in Russia. Jurídicas CUC, 17(1), 253-276. DOI: http:// dx.doi.org/10.17981/juridcuc.17.1.2021.09

\section{Resumen}

Mediante el presente artículo se analizarán las características del desarrollo de los servicios públicos y las posibilidades de aplicar esta experiencia para Rusia y otros países. El objetivo del artículo es realizar un análisis comparativo de los modelos de desarrollo de instituciones de servicio público en el mundo; determinar sus características comunes y distintivas, que deben tenerse en cuenta al determinar los objetivos de la reforma de la institución de servicio público en Rusia. A través de una metodología comparativa se revisan los modelos de desarrollo de las instituciones de servicio público en países extranjeros. Se examinan y analizan las principales etapas de la reforma de servicio público y se determinan las direcciones generales y distintivas de dicho proceso. Al determinar los objetivos principales de la reforma de la institución de servicio público en Rusia, es necesario tener en cuenta las experiencias de los Estados extranjeros, que tienen resultados positivos. En particular, se debe prestar atención a los cambios que se produzcan en cada etapa de la reforma, a saber: marco jurídico y funcionamiento de servicio público, la estructura orgánica de servicio público, política de personal, la provisión por funcionarios de los servicios públicos a los ciudadanos, el desarrollo de la sociedad de la información. Se tuvieron en consideración para las perspectivas de análisis a instituciones de servicio público de países desarrollados. Se concluye que un análisis comparativo de los procesos de mejora conducirán a las bases de una reforma del instituto de servicio público ruso para conseguir los logros y resultados que se requieren.

Palabras clave: Estructura del Estado; institucionalización; reforma; salario

\section{Abstract}

This article studies the specific development of public service and the possible application of foreign experience in Russia and other countries. The article aims at conducting a comparative analysis of development patterns typical of the institution of public service in the world and determining their general and distinctive features that should be considered when identifying the objectives of reforming the institution of public service in Russia. Results. The article considers development patterns typical of the institution of public service in foreign countries. The main stages of reforming public service have been examined and analyzed, as well as general and distinctive features of this process have been determined. Conclusions. While defining the main objectives of reforming the Russian institution of public service, it is necessary to consider the positive experience of foreign countries. In particular, attention should be paid to the changes at each stage of reforming, namely: the legal support of public service, the organizational structure of public service, personnel policy, the provision of public services to citizens by state employees, and the development of information society. The prospects for further research are to study the specific development of the institution of public service in developed economies. An in-depth comparative analysis of improving such an institution will enable to use the best foreign achievements in reforming the Russian institution of public service.

Keywords: Institutionalization; reform; state structure; wage 


\section{INTRODUCTION}

\section{Problem statement}

Public service occupies the most important place in the public administration system. In the process of evolutionary changes in the legal regulation of legal relations in this area, a complex institution of law was formed, which includes the regulation of the activities of the state apparatus. This institution has developed as a complex, multidimensional phenomenon in the legal system. Thus, public service is a complex legal institution that includes legal norms regulating the construction, organization and functioning of the public service system and establishing the legal status of civil servants (rights, obligations, restrictions, prohibitions, social guarantees, responsibility), procedures of civil servants' powers and functions established by them by law, as well as the mechanism of admission to service, its passage and termination.

The institution of public service plays a key role in the mechanism of state power since in practice the functions of public administration are carried out by specially trained civil servants who are part of the state apparatus.

The institution of public service is heterogeneous in different countries, which is expressed in different terms, denoting it: "public service", "civil service", "government service".

Many countries, including, for example, Brazil, Italy, Ireland, Kazakhstan, Mongolia, Uzbekistan and Russia, are currently concerned with the development of the institution of public service. The scientific interest in this sphere is associated with: the transformation of political systems; new forms of interaction between the institution of public service and citizens, their associations, civic institutions; new methods of citizens' participation in public administration; the need to improve the existing legal and regulatory framework; the improved level of professional training for civil servants; the high quality of public services. In the late $20^{\text {th }}$ century, countries began to actively form and implement their development patterns for the institution of public service. 
The patterns used in the countries of North and South America, Europe and Asia are determined by certain sequential and interconnected stages that provide changes both in the structure of public authorities and their powers. However, their national and regional specifics, as well as the role of the state in reforming, influence the process of improving public service. Therefore, it is crucial to analyze the foreign experience of those countries that are located in the same region with Russia (Poland, Hungary), and the other countries with different state structures and specific activities of public authorities (USA, UK, Germany, France) to effectively reform the Russian institution of public service. On the one hand, it is a good incentive to carry out reforms. On the other hand, it allows studying foreign experience and avoiding mistakes in the formation of a renewed institution of public service in Russia.

The current state of the institution of public service in Russia is characterized primarily by legislative support. Thus, the legal regulation of public service is carried out based on the Federal Law "On the System of Public Service in the Russian Federation" (Law N 58-FZ, 2003). According to it, the system of public service in Russia includes civil public service, military service and other types of public service carried out in law enforcement agencies. Legal regulation of civil public service is carried out based on the Federal Law "On Civil Public Service in the Russian Federation" (Law N 79-FZ, 2004), as well as the Federal Law "On the Features of Federal Civil Public Service in the System of the Ministry of Foreign Affairs of the Russian Federation" (Law N 205-FZ, 2010).

The issues of military service are regulated by the general federal laws "On Military Duty and Military Service" and "On the Status of Military Personnel" adopted back in 1998 (Law Federal N 53-FZ), as well as special federal laws on state bodies that provide for military service (adopted in 1995, 1996, 1997 and 2016).

The issues of other types of public service are regulated by separate special laws for law enforcement agencies (adopted in 1994, 1995, 1997, 2010, 2011, 2016, 2018 and 2019). 
Besides, hundreds of decrees of the President of the Russian Federation and resolutions of the Government of the Russian Federation have been adopted and are in effect, regulating the functioning of the entire institution of public service and its elements. At the same time, the process of reforming the public service system continues to increase its efficiency and solve the problems existing in this area of public administration.

Thus, regular monitoring of the practice of applying the legislation of the Russian Federation in the field of public service has not yet been unified. The organizational model of the federal public service management body and uniform principles for the creation and functioning of such regional bodies have not been developed. A unified system of scientific and methodological support and provision of advisory assistance to state bodies, both federal and regional, on public service issues has not been created. The procedure for the participation of independent experts in the work of competition and certification commissions, as well as commissions for compliance with the requirements for official conduct and settlement of conflicts of interest, needs to be optimized. An effective system of interaction between civil society institutions and the media with state bodies, neutralizing the possibility of unlawful interference in the activities of civil servants, has not developed. The imbalances in wages and pension provision for civil servants who have equal legal and official status have not been eliminated. Programs aimed at increasing the prestige of public service and forming a positive attitude of citizens towards civil servants are not being properly implemented. The performance indicators of civil servants are poorly linked to their work performance, the achievement of goals and the priorities of state bodies. The level of the basic wage for civil servants practically does not depend on the results of their work. The system of additional professional education of civil servants is also insufficiently aimed at increasing the effectiveness of their professional service activities. 


\section{LITERATURE REVIEW}

In recent years, the issue of improving the institution of public service has become especially relevant and has been studied by many Russian and foreign scholars. Modern scholars focus on international experience in the development and functioning of public service, organizational issues, features of the main models, and areas of reforming. These issues are examined by the following authors: Bartsits (2019), Bogatyrev (2019), Borshchevskii (2017a, 2017b, 2018), Bratanovskaya (2016), Zhumagulov (2016), Zubov (2017), Ivleva (2018), Mamitova (2017), Matveev (2016), Slatinov \& Merkulova (2019), Surmanidze \& Kirillovykh (2018), Chekin (2018), Dudin, Ivashchenko, Gurinovich, Tolmachev \& Sonina (2019), and others who fully or partially specialize in this subject. Although there is a significant number of scientific studies, many important issues remain unaddressed and require a comprehensive study with due regard to the rapid socio-economic development of society. In particular, it is necessary to consider models of reforming public service and the main parameters that form their basis.

\section{Research hypothesis}

The process of reforming the institution of public service is characterized by objective laws that should be considered when reforming public service in Russia.

The article aims at conducting a comparative analysis of development patterns typical of the institution of public service in foreign countries and determining their general and distinctive features that should be considered when identifying the objectives of reforming the institution of public service in Russia.

\section{Metodology}

Throughout the study, we used the following methods: the method of induction to determine a sequence of stages; the comparative 
method for selecting reference points of the study; structural and functional methods for highlighting the functions of state bodies; structural and graphical methods for demonstrating the study results.

\section{RESULTS}

To conduct a detailed analysis of the development patterns typical of the institution of public service, we selected some of the most developed countries from each group that have common and distinctive features (Ponkin, 2019; Klyuzina, Berendeeva \& Zosimova, 2019; Meyer-Sahling \& Mikkelsen, 2016; Smalskys \& Urbanovič, 2017); countries with an open model of public service (the United States); a closed model of public service (France, Germany); a mixed model of public service (the United Kingdom, Poland, Hungary).

Based on the theory of public administration, over the past 20 years, these countries have carried out important administrative reforms that have led to positive changes in the development of the institution of public service (Table 1).

Today, the most common models of public service in developed countries are as follows: career-oriented (closed), official, and mixed. Most countries in the European Union utilize the careeroriented model. It limits the free movement of public servants within their careers. The closed model of public service has the following features: a civil servant hired for a certain position can move to the highest level during a certain period; the employment of a civil servant in some position depends on their level of training, i.e. there are certain requirements for the level of education; the appointment of a civil servant to the lowest-level posts and further career advancement has a clearly defined principle of subordination; the statutory norms of conduct for public servants are legally enshrined. Such a model is developing in France, Germany, Denmark, and Spain. 
TABLE 1.

Similarity and difference matrix for the institution of public service in the world

\begin{tabular}{|c|c|c|c|c|c|c|}
\hline \multirow{2}{*}{ Features } & \multicolumn{6}{|c|}{ Countries } \\
\hline & Great Britain & Germany & Poland & USA & Hungary & France \\
\hline $\begin{array}{l}\text { Model of public } \\
\text { service. }\end{array}$ & Mixed. & Closed. & Mixed. & Open. & Mixed. & Closed. \\
\hline $\begin{array}{l}\text { Main stages of } \\
\text { reforming public } \\
\text { service. }\end{array}$ & $\begin{array}{l}1979-1982 ; \\
1983-1986 ; \\
1987-\text { present }\end{array}$ & $\begin{array}{l}1968-1975 \\
1975-1990 \\
\text { the } 1990 \mathrm{~s}\end{array}$ & $\begin{array}{l}\text { 1989-1996; } \\
\text { 1997-2003 }\end{array}$ & $\begin{array}{l}1978-1991 \\
1992-2000 \\
2001-2003\end{array}$ & $\begin{array}{l}1989 \\
1990-1995 \\
1996-1999\end{array}$ & $\begin{array}{l}1981-1986 ; \\
1986-1988 ; \\
1988-\text { present }\end{array}$ \\
\hline $\begin{array}{l}\text { Reform } \\
\text { directions. }\end{array}$ & $\begin{array}{l}\text { Reduction in } \\
\text { the number of } \\
\text { civil servants; } \\
\text { involvement of } \\
\text { consultants into } \\
\text { the sphere of } \\
\text { public service; } \\
\text { comprehensive } \\
\text { cost verification } \\
\text { for "maximum } \\
\text { utility". }\end{array}$ & $\begin{array}{l}\text { Improvement of the } \\
\text { system of training } \\
\text { and retraining } \\
\text { of civil servants; } \\
\text { increase in the } \\
\text { vertical mobility } \\
\text { of civil servants; } \\
\text { promotion of } \\
\text { cooperation in } \\
\text { the active-ties of } \\
\text { ministers. }\end{array}$ & $\begin{array}{l}\text { Restructuring of } \\
\text { the administrative- } \\
\text { territorial structure } \\
\text { of the state; reform of } \\
\text { the system of public } \\
\text { finance; testing of } \\
\text { applicants for the } \\
\text { position of civil } \\
\text { servants. }\end{array}$ & $\begin{array}{l}\text { Focus on } \\
\text { changes to the } \\
\text { methods used in } \\
\text { public service; } \\
\text { implementation of } \\
\text { reforms by political } \\
\text { appointees rather } \\
\text { than civil servants; } \\
\text { verification of the } \\
\text { effectiveness of } \\
\text { state institutions. }\end{array}$ & $\begin{array}{l}\text { Decentralization; } \\
\text { formation of local } \\
\text { councils concerned with } \\
\text { issues of territorial } \\
\text { development; creation } \\
\text { of conditions for the } \\
\text { development of the } \\
\text { private sector at the } \\
\text { state level; changing the } \\
\text { hierarchical system of } \\
\text { public administration. }\end{array}$ & $\begin{array}{l}\text { Decentralization; } \\
\text { decomposition; } \\
\text { improvement of the } \\
\text { quality of public services. }\end{array}$ \\
\hline $\begin{array}{l}\text { Public } \\
\text { administration } \\
\text { authorities. }\end{array}$ & $\begin{array}{l}\text { Prime Minister, } \\
\text { Public Service } \\
\text { Council. }\end{array}$ & $\begin{array}{l}\text { Federal Ministry of } \\
\text { the Interior. }\end{array}$ & $\begin{array}{l}\text { Civil Service } \\
\text { Department. }\end{array}$ & $\begin{array}{l}\text { Human Resources } \\
\text { Management } \\
\text { Council, Merit } \\
\text { Systems Protection } \\
\text { Board. }\end{array}$ & $\begin{array}{l}\text { Ministry of the Interior, } \\
\text { Ministry of Public } \\
\text { Administration and } \\
\text { Justice. }\end{array}$ & $\begin{array}{l}\text { Chief Directorate of } \\
\text { Administration and } \\
\text { Public Service under } \\
\text { the Ministry of Public } \\
\text { Service. }\end{array}$ \\
\hline $\begin{array}{l}\text { Public service } \\
\text { laws. }\end{array}$ & $\begin{array}{l}\text { "Next Steps" } \\
\text { Public Service } \\
\text { Program of } 1988 \\
\text { (acts as a law). }\end{array}$ & $\begin{array}{l}\text { Federal Law on } \\
\text { Officials of } 1953 .\end{array}$ & $\begin{array}{l}\text { Public Service Act of } \\
2008 .\end{array}$ & $\begin{array}{l}\text { Law "On Public } \\
\text { Service" of } \\
\text { 1883; Law "On } \\
\text { Reforming Public } \\
\text { Service" of } 1978 \text {. }\end{array}$ & $\begin{array}{l}\text { Law "On Public Service" } \\
\text { No. XXIII (1992). }\end{array}$ & $\begin{array}{l}\text { Law on Central Public } \\
\text { Service of January 11, } \\
1984 \text { No. 84-16; Law on } \\
\text { the Rights and Obligations } \\
\text { of Civil Servants of July } \\
\text { 13, } 1983 \text { No. 83-634. }\end{array}$ \\
\hline
\end{tabular}

Source: Romanovsky (1999), Adamovich (2014), Soldatov and Bratanovsky (2020), Farnham and Horton (1996), Das (1998), Bekke \& Meer (2000), Demmke \& Moilanen (2010), Van der Meer, Raadschelders \& Toonen (2015). 
In France, persons who win the competition for a vacant position in public service accept this post to make an official career. The state defines four categories of posts available for civil servants: (A) occupied by senior officials with higher education and an appropriate license (diploma awarded after the successful completion of three years of full-time studies), (B) persons with at least the Bachelor's degree (completed secondary education), (C) persons with incomplete secondary education, and (D) persons with primary education.

Officially, there is also the fourth category (D) in central public service which brings together operating staff. However, this category is gradually disappearing after the agreement concluded with trade unions in 1990 and is equated with the $\mathrm{C}$ category. Moreover, the $\mathrm{D}$ category is not even provided for by the Law on Territorial Public Service (Law No 84-53, 1984).

One of the most important administrative reforms in France began in the early 1980s and comprised three stages. The first stage was marked by an increase in the number of civil servants and the development of local self-government. During this period, the state adopted about 40 regulatory legal acts aimed at power decentralization. The second stage took place during the so-called "divided rule" which differed from the first. It was characterized by the privatization of public enterprises and a decrease in the number of employees. In 1988, left-wing parties got back and became the basis for the unification of public and private institutions, which drew more attention to forming ties with the market. The last stage of reforming began in the late 1980s and continues to this day. It was marked by amendments to the Constitution of France (1958).

Thus, this reform mainly aimed at decentralization, the deconcentration of powers and responsibilities, the increased efficiency of civil servants, and the improved quality of public services. Throughout such deconcentration, the planning system was improved, central departments were reorganized, and new types of state structures were developed. At the same time, the Charter on the Provision of Public Services (1992) aimed at improving the quality of public services provided to citizens. This document regularly assessed the provision of services and conducted various experiments to identify factors that could influence this process. 
Like France, Germany uses the closed model of public service but it has specific features, in particular the training and selection of civil servants, as well as the stages of public service reforming. There are four levels of public service: simple, medium, high, and higher. To get a low-level position, a candidate needs to have a certificate of graduating from primary school (Hauptschule). A candidate with a secondary school certificate (Realschule) and appropriate professional training can seek a middle-level position. High-level positions are available for persons with a university degree (Fachhochscule) or a certificate of completing a high school course that gives the right to enroll in institutions of higher education. Higher positions are open only for candidates having at least a completed three-year course in higher education and passing an appropriate exam (The Federal Public Service, 2014).

If compared to France, the German public service was much easier to reform. This is because the Weberian bureaucracy remained more stable in the country. Furthermore, local self-government (therefore, no need for decentralization) and society were quite developed in the 1980-90s. The main reforms of the German public service are presented in Table 2.

TABLE 2 .

Reforming the German public service

\begin{tabular}{|c|c|}
\hline Stage & Reform objective \\
\hline $1968-1975$ & To improve public administration at all levels (federal, state, local). \\
\hline $1975-1990$ & To shift focus to local self-government. \\
\hline $1990 \mathrm{~s}$ & $\begin{array}{l}\text { To enhance the role of German states in international affairs; to } \\
\text { improve the redistribution of income between the federal authority and } \\
\text { its constituent territories. }\end{array}$ \\
\hline
\end{tabular}

Source: Compiled by the authors.

The main directions of reforming the German public service were: the enlargement of self-governing territorial entities; the transfer of some state functions to the local level, i.e. power decentralization when certain powers are delegated to local authorities; an increase in the vertical mobility of civil servants. 
The reforms of public service conducted in the US and UK had many similarities, although these countries differ in their state structure, public administration system, and form of government. They utilized a model of responsible authority implying the partnership between public and private sectors, competition between state bodies and the private sector in the implementation of state tasks, the distribution of responsibility between sectoral state bodies and hierarchical levels, and mandatory selective entry for public service. In contrast to the French reforming of public service, the German authorities focused on reducing the number of civil servants and achieving a certain result rather than the process efficiency. The institution of public service in the US and UK was reformed in the 1980-90s: the early 1980s in the UK and the mid1990 s in the US.

The third phase of reforming the US public service began under the leadership of Bush Jr., who adopted the President's Management Agenda in 2001. This document comprised the following five areas: strategic human capital management; competition between public and private sectors; increased financial performance; development of electronic governance; results-based budgeting. The above-mentioned reforms resulted in the development of evaluation techniques entitled the Checklist of the President's Management Agenda (2002).

TABLE 3.

Reforming the public service in the UK

\begin{tabular}{cl}
\hline \multicolumn{1}{c}{ Stage } & \multicolumn{1}{c}{ Reform objective } \\
\hline $1.1979-1982$ & $\begin{array}{l}\text { To reduce government expenditures and downsize the number } \\
\text { of civil servants. } \\
\text { The reform was carried out under the slogan "saving, productivity, } \\
\text { efficiency" which provided for the widespread privatization of } \\
\text { public enterprises; to improve the evaluation function of central } \\
\text { ministries and senior management. }\end{array}$ \\
2.1983-1986 1987 - present & $\begin{array}{l}\text { To increase decentralization, improve the quality of public } \\
\text { services and customer orientation, promote the development of } \\
\text { local self-government. }\end{array}$ \\
\hline
\end{tabular}

Source: Compiled by the authors. 
The main directions of reforming the public service in Great Britain that began in 1979 were as follows: the effectiveness and efficiency of public service and the initiative of citizens. The stages of such reforming are presented in Table 3.

However, public service reforms in the UK and the US were conducted much earlier. In the UK, this process started in the $19^{\text {th }}$ century. In 1848 , a special commission was formed to study the possibilities for reforming public service and recommendations given by ministries and departments. The most effective and useful were the proposals of G. Travelyanov who studied the specifics of the British public service and its shortcomings. The scholar offered a new system of developing public service that became widespread in the US and was called the "merit system". The first reforms in the UK laid the foundation for: distinguishing between political and career-oriented government posts; forming a complex system of different classes for civil servants; employing civil servants upon successful examination and getting a college degree. Thus, Flynn \& Strehl (1996) note that the UK used the slogan developed back in 1850 to denote a new selection system for public service: "public service offers a career open to talents" (p. 63).

We should also pay attention to the formation of the institution of public service in European countries that have different forms of government, in particular Poland and Hungary. Before the reforms of the 1990s, Hungary experienced certain difficulties in public service due to a significant amount of public debt, employment problems, and patronage when appointing civil servants. To overcome these challenges, the authorities focused on power decentralization and the formation of regional councils that should deal with issues of territorial development and training for civil servants to prepare them for solving their tasks in the field of public service. The main reforms of the Hungarian public service are presented in Table 4. 
TABLE 4.

Reforming the Hungarian public service

\begin{tabular}{ll}
\hline \multicolumn{1}{c}{ Stage } & \multicolumn{1}{c}{ Reform objective } \\
\hline 1.1989 & $\begin{array}{l}\text { To abolish many legal acts regulating public service in the } \\
\text { former socialist state. }\end{array}$ \\
& To adopt a new legislative framework for public service; to \\
& transfer more decision-making powers to local authorities; \\
& to improve the system of providing public services to \\
citizens. & To distinguish between political leadership and \\
administrative professional officials; to develop & \\
& e-government.
\end{tabular}

Source: Compiled by the authors.

Hungary is among few countries that managed to reform public service on time. The results of reforming the Hungarian institution of public service in the 1990s were as follows: decreasing number of official employees, higher efficiency of public service, improved quality of public services provided to citizens, simplified legislation on public service and identification of five categories of state authorized persons (civil servants, employees providing public services (teachers, employees of medical, and other institutions mainly managed by local authorities), employees working in accordance with the Labor Code, officials responsible for compliance with the existing law (police, customs, armed forces), specialists (judges and other legally educated persons).

Like Hungary, Poland belongs to the former socialist countries which were not circumvented by the same problems in public service as most countries in the world at the end of the 20th century. If certain states already had some experience in reforming this institution (the US, the UK, Germany, and France), Poland and other countries of Eastern Europe did this for the first time. First of all, the state faced the need to form a new state form of government, a system of public authorities, and an institution of public service. The reforms conducted in the Polish institution of public service are presented in Table 5. 
TABLE 5.

Reforming the public service in Poland

\begin{tabular}{|c|c|}
\hline Stage & Reform objective \\
\hline 1. $1989-1996$ & $\begin{array}{l}\text { The preparatory stage was marked by a political struggle for } \\
\text { power and a change in territorial division to reduce the number } \\
\text { of voivodships (regions into which the country is divided) that } \\
\text { hindered the effective democratization and decentralization of } \\
\text { powers. }\end{array}$ \\
\hline 2. $1997-2003$ & $\begin{array}{l}\text { During the period of "real steps", a new model of public service was } \\
\text { formed utilizing the experience of the EU countries in building } \\
\text { a democratic and transparent government, creating new ethical } \\
\text { regulation of public service, increasing state responsibility for the } \\
\text { decisions made. }\end{array}$ \\
\hline
\end{tabular}

Source: Compiled by the authors.

Since 2000, the "Friendly administration" program has been implemented in Poland that plays an important role in building a positive image of the Polish public service and aims at creating positive relations with citizens. Its ideology proceeds from the consideration of authorities as providers of different services to citizens and institutions. The basic principles of the program are as follows: a citizen is a client of public administration; defining the tasks of each civil servant is necessary to improve the quality of public services; the implementation of this state program depends on the interest of both managers and all administration staff in the improved image of government bodies; the consideration of public as a partner in creating citizen-friendly administration (Ivleva, 2018). In 2002, the Information Center of Public Service was established in Poland that aims at giving citizens and all civil servants access to information on the types of public services and areas of activity of certain public authorities.

Thus, the reforms of public service had their specifics in each of the above-mentioned countries. Common trends are associated with historical conditions of their development, reforms of their state apparatus, different state structures, territorial affiliations, political processes, etc. 


\section{Discussion}

When studying and analyzing foreign experience in forming the institution of public service, the Russian authorities can determine which experience is the most effective and can be adapted to the existing conditions. One of the results of the conducted analysis is to form such a model of public service that would be able to respond and quickly adapt to constant changes in the state.

When forming its own institution of public service, each state is guided by personal needs and social changes, according to which it chooses a development strategy. In our opinion, the reforms of public service pursue the following goals:

1. To find a balance between political and administrative posts;

2. To ensure the simultaneous dynamics and stability of public service;

3. To increase the openness of public service and the quality of public services provided to citizens, as well as to focus on the needs of the population;

4. To market public service using market principles and to create non-state structures that cooperate with the government in order to fulfill certain functions;

5. To promote decentralization when the center for implementing state programs is shifted to lower-level authorities;

6. To introduce responsibility for the result of some work rather than the process;

7. To expand the scope of competitive examinations for public positions;

8. To reduce the number of civil servants and establish their salaries in conformity with the results of their work (Figure 1 and Figure 2). 
30.6

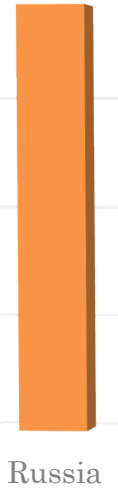

Russia

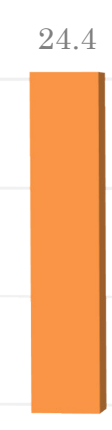

23.7
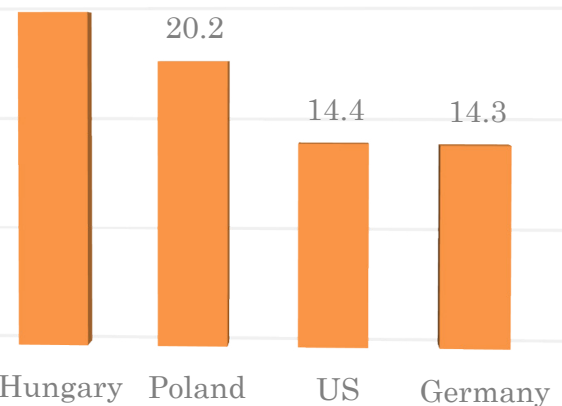

20

24 .

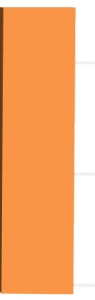

16

8.

Germany UK

Figure 1. The share of civil servants in the working age population, $\%$. Source: Compiled by the authors using sources from Organization for Economic Cooperation and Development (OECD, 2020) and Rosstat (2020).

By how many times the salary of highprofile officials exceeds the average salary by country?

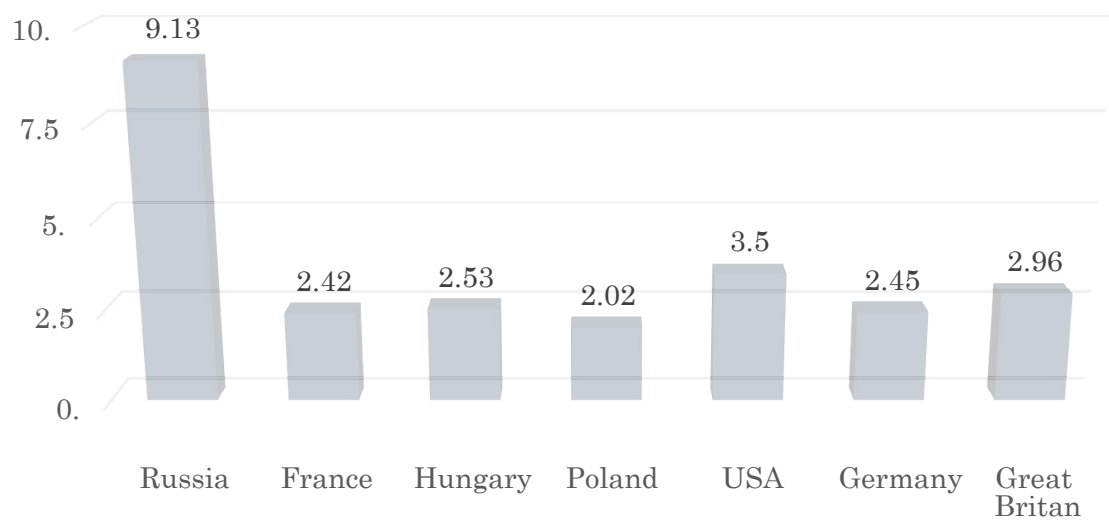

Figure 2. The ratio of salaries earned by civil servants and the average salary by country in the currencies of specified countries.

Source: Calculated by the authors using sources Okriashvili, Gurinovich,

Pavlyuk \& Yakupov (2018), Oprescu \& Enescu (2020) and OECD (2020).

The above-mentioned strategies are to overcome the problems in public service that became especially widespread at the end of the $20^{\text {th }}$ century. While studying the formation of public service in various countries, Manning \& Parison (2003) revealed the following problems of this process (Table 6). 
TABLE 6.

Reforming public service at the end of the 20th century

\begin{tabular}{|c|c|c|c|c|c|c|c|c|}
\hline Problems & 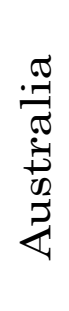 & $\stackrel{\vartheta}{\emptyset}$ & 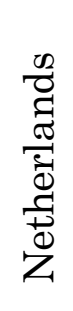 & 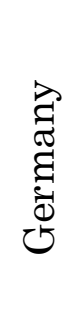 & 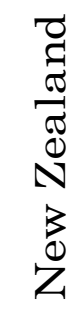 & $\begin{array}{l}\widetilde{\Xi} \\
\text { శ్ర } \\
\text { م. } \\
\end{array}$ & $\stackrel{\varpi}{\square}$ & $\begin{array}{l}\vec{D} \\
\tilde{\sigma} \\
00 \\
\Xi \\
\Xi\end{array}$ \\
\hline $\begin{array}{l}\text { Government expenditures on salaries } \\
\text { of civil servants. }\end{array}$ & + & + & + & + & + & + & + & + \\
\hline Patronage. & & & & & & & & + \\
\hline State employment and tenure. & + & + & & & + & & & \\
\hline Ineffective financial incentives. & & & & & + & & & \\
\hline High-level corruption. & & & & & & + & & + \\
\hline The low quality of public services. & + & + & & + & + & + & + & + \\
\hline
\end{tabular}

Source: Compiled by the authors (Manning \& Parison, 2003, p. 22).

Despite the common objective and strategy, each country selects its own way of making changes to the institution of public service. It depends on the historical formation of states, their economic development, political and administrative structure, selected models of public service. According to the specifics of reforming the institution of public service, scholars (Manning \& Parison, 2003; GamanGolutvina, 2007; Wollmann, 2010) have determined several groups of states:

1. The Anglo-Saxon countries (Australia, the UK, Ireland, New Zealand, the US);

2. The "Napoleonic" countries (Belgium, Greece, Spain, Italy, Luxembourg, the Netherlands, Portugal, France);

3. The "German" countries (Austria, Germany, Switzerland);

4. The Scandinavian countries (Denmark, Norway, Finland, Sweden);

5. The post-socialist countries (Bulgaria, Poland, Romania, Hungary, the Czech Republic). 


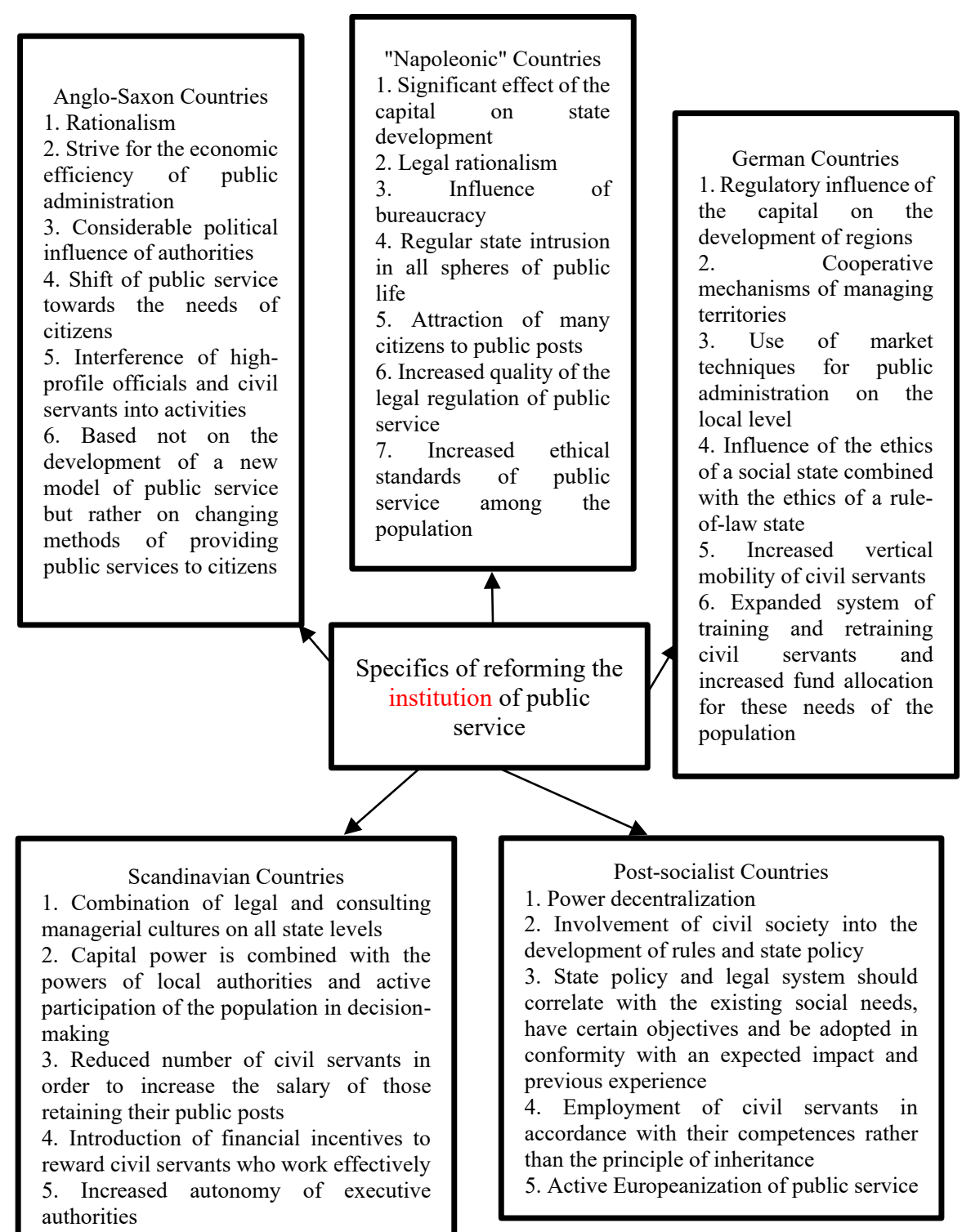

Figure 3. The specifics of reforming the institution of public service in foreign countries. Source: Compiled by the authors.

This classification of states is not accidental. At the same time, the allocation of some countries does not mean that the others have not reformed their public service. This means that the selected direction of reforming is typical of several states. Certain groups of countries develop their public service according to a certain scenario, whose main features are presented in Figure 3. 


\section{Conclusions}

While studying the specific formation of the institution of public service in the US, UK, Germany, France, Hungary, and Poland, we drew the following conclusions and generalizations.

1. In most countries, the 1980s and 1990s were marked by the most ambitious reforms in the sphere public service, which is associated with the need to improve the efficiency and quality of the public services provided by public authorities, altered personnel policy, separation of political and managerial functions, and effective implementation of state policy in different areas of public life. In this period, administrative reforms were conducted in different directions in various states but the focus was on the functioning of public service, which contributed to the formation of several development patterns typical of the institution of public service: Anglo-Saxon, German, Napoleonic, Scandinavian, and post-socialist.

2. A comparative analysis of reforming the institution of public service in these countries has revealed the following features:

- Models of public service can be of the following types: open (the US), closed (Germany, France); mixed (the UK, Poland, Hungary);

- The reform period in most of the above-mentioned countries can be divided into three main stages: the analysis of social problems; the search for a new development pattern suitable for the institution of public service; the implementation of certain approaches and consideration of the results obtained;

- Areas of reforming are as follows: the Anglo-Saxon model seeks to increase the economic efficiency of public administration, i.e. focuses on the result of some activity rather than on the process itself, as well as improves the quality of public services and reduces the number of civil servants; the German model uses market mechanisms in public administration at the local level, as well as increases the vertical mobility of civil servants and expands their number; the "Napoleonic" countries aim at legal rationalism and regular participation of state in all spheres of public life, improving the quality of legal regulation of public service; the post-socialist states lay a course for decentralization, changes in the administrative-territorial structure, and the Europeanization of public service. 
3. One of the most important areas of administrative reforming in the above-mentioned states was improving the quality of public services provided to citizens. To solve this issue, it was necessary to develop and adopt an appropriate regulatory framework for public service, adopt state programs ensuring the quality of public services, promote power decentralization, pay more attention to the result of activities and needs of citizens, develop information society to improve cooperation, and increase the trust of citizens towards their government.

4. The study hypothesis was confirmed. The process of reforming the institution of public service has the following patterns: the formation of flexible management systems that can easily adapt to new conditions, the increasing openness of public service, and the use of tools and mechanisms of private economic management.

5. While determining the main objectives of reforming the Russian institution of public service, we should consider the positive experience of foreign countries. In particular, attention should be paid to the changes at each stage of reforming, namely: the legal support of public service, the organizational structure of public service, personnel policy, the provision of public services to citizens by state employees, and the development of information society.

The prospects for further research are to study the specific development of the institution of public service in developed economies. An in-depth comparative analysis of improving such an institution will enable to use the best foreign achievements in reforming the Russian institution of public service.

\section{REFERENCES}

Adamovich, A. S. (2014). Reforming the public service system of the Russian Federation. State Service, 1(87) 80-83. Available: https://pa-journal.igsu.ru/articles/r36/2007/ 
Bartsits, I. N. (2019). Best foreign practices of personnel management in the public administration system. Public Administration, 21(3), 29-31. https://doi.org/10.22394/2070-83782019-21-3-29-31

Bekke, A. \& Meer, F. M. (eds.). (2000). Civil service systems in Western Europe. Cheltenham/Northampton: Edward Elgar Publishing.

Bogatyrev, E. D. (2019). Methodological Foundations of reforming and developing Civil Public Service. State Service, 21(3), 14-17. https://doi.org/10.22394/2070-8378-2019-21-3-14-17

Borshchevskii, G. A. (2018). Institution of public service in the political system of the Russian society. [Monograph]. Moscow: Yurait Publishing House.

Borshchevskii, G. A. (2017a). The US experience of transforming the institution of public service in the conditions of political reforms. USA and Canada: economics, politics, culture, (6), 98-115. Available: http://iskran.ru/zhurnal-ssha-kanada/arxiv-nomerov/2017-god/06-570-iyun/

Borshchevskii, G. A. (2017b). Reforming bureaucracy: comparing the experience of Great Britain and Russia. Russia and the Modern World, (3), 260-279. https://doi.org/10.31249/ $\mathrm{rsm} / 2017.03 .16$

Bratanovskaya, M. S. (2016). Administrative and legal issues of public service in Russia. Society and law, 10, 87-89.

Chekin, M. A. (2018). Payment for official activities conducted by civil servants in Russia. History, practice, experiments and perspectives. Moscow: State University - Higher School of Economic.

Das, S. K. (1998). Civil service reform and structural adjustment. Oxford: Oxford University Press.

Demmke, C. \& Moilanen, T. (2010). Civil Services in the EU of 27: Reform Outcomes and the Future of the Civil Service. Frankfurt am Main: Peter Lang. 
Dudin, M. N., Ivashchenko, N. P., Gurinovich, A. G., Tolmachev, O. M. \& Sonina, L. A. (2019). Environmental Entrepreneurship: Characteristics of Organization and Development. Entrepreneurship and Sustainability Issues, 6(4), 18611871. http://doi.org/10.9770/jesi.2019.6.4(22)

Farnham, D. \& Horton, S. (eds.). (1996). Managing the new public services. London: Macmillan International Higher Education.

Federal Republic of Germany. Federal Ministry of the Interior. (2014). The federal public service. An attractive and modern employer. Berlin: Federal Ministry of the Interior. Available: https://www.bmi.bund.de/SharedDocs/ downloads/EN/publikationen/2014/federal-public-service. pdf?__blob=publicationFile

Flynn, N. \& Strehl, F. (eds.). (1996). Public sector management in Europe. London: Prentice Hall.

Gaman-Golutvina, O. V. (2007). The changing role of the state in the context of public administration reforms: domestic and foreign experience. Polis. Political Studies, (4), 24-45. http://doi.org/10.17976/jpps/2007.04.03

Ivleva, A. E. (2018). The concept and nature of public service. Proceedings of the Scientific Conference of the Russian Academy of National Economy and Public Administration of the Russian Federation (pp. 141-144). Voronezh: Publishing Polygraphic Center.

Klyuzina, S. V., Berendeeva, A. B. \& Zosimova, L. A. (2019). Civil public service in the light of modern social theories and innovative technologies. Ivanovo: CHOU VO "Institute of Management".

Mamitova, N. V. (2017). The specific legal regulation of the institution of public service in foreign countries. Society and law, 1, 158-162.

Manning, N. \& Parison, N. (2003). The reform of public service: international experience. Moscow: All World. 
Matveev, S. P. (2016). The system of public service: development and improvement issues. Bulletin of the Voronezh Institute of the Ministry of Internal Affairs of Russia, 1, 131137.

Meyer-Sahling, J. H. \& Mikkelsen, K. S. (2016). Civil service laws, merit, politicization, and corruption: The perspective of public officials from five East European countries. Public administration, 94(4), 1105-1123.

OECD. (2020). Government. [Online]. Availbale: https://data.oecd. org/government.htm

Okriashvili, T. G., Gurinovich, A. G., Pavlyuk, A. V. \& Yakupov, A. G. (2018). About the need to eliminate violations of the constitutional principle On equality of the Legislative, Executive and Judicial branches of government in terms of Remuneration and Pensions paid to Civil Servants from Office of the Supreme State Power Bodies of the Russian Federation. Contemporary Dilemmas: Education, Politics and Values, 6(1), 1-20. Available: https://repository.kpfu. $\mathrm{ru} /$ ?p_id=244320

Oprescu, M. \& Enescu, C. (2017). Some Aspects of Civil Service Pay Policy. Strategii Manageriale, p. 62.

Ponkin, I. V. (2019). The theory of public administration. Moscow: INFRA-M.

République Française. Conseil des ministres. (18 mar. 1992). Charter on the Provision of Public Services. [Online]. Available: https://www.vie-publique.fr/discours/156710conseil-des-ministres-du-18-mars-1992-la-charte-des-services-publics\#: :text=\%2D\%20La\%20charte\%20regroupe\%20les\%20actions,les\%20entreprises\%20\%3B\%20 services\%20publics\%20de

République Française. (26 jan. 1984). Portant dispositions statutaires relatives à la fonction publique territoriale. [Loi $n^{\circ}$ 84-53]. Retrieved from: https://www.legifrance.gouv.fr/ loda/id/LEGITEXT000006068842/ 
République Française. (4 oct. 1958). Constitution of France. [Online]. Available: https://www.conseil-constitutionnel.fr/ sites/default/files/as/root/bank_mm/anglais/constiution_ anglais_oct2009.pdf

R.F. State Duma. (jul. 27, 2010). On the Features of Federal Civil Public Service in the System of the Ministry of Foreign Affairs of the Russian Federation. [Law 205-FZ]. Available: http://www.consultant.ru/document/cons_doc_ LAW_103018/

R.F. State Duma. (jul. 27, 2004). On Civil Public Service in the Russian Federation. [Law N 79-FZ]. Available: http://www. consultant.ru/document/cons_doc_LAW_48601/

R.F. State Duma. (mar. 28, 1998). On Military Duty and Military Service. [Law Federal N 53 F-Z]. Available: http:// www.consultant.ru/document/cons_doc_LAW_18260/ d8ba8171f6e944b1dc563df7d03c02836a574238/

R.F. State Duma. (may. 23, 2003). On the System of Public Service in the Russian Federation. [N 58-FZ]. Available: http:// www.consultant.ru/document/cons_doc_LAW_42413/

Romanovsky, N. V. (1999). Sociology and the Institution of Public service. Sociological Research, 2, 14-24.

Rosstat. (2020). Federal State Statistic Service. [Online]. https:// rosstat.gov.ru/folder/10705

Slatinov, V. B. \& Merkulova, K. G. (2019). Reforming bureaucracy as a condition for forming "national development: perspectives and limitations of modernizing public service in Russia. Central Russia Social Science Bulletin, 14(1), 161-177. Smalskys, V. \& Urbanovič, J. (2017). Civil service systems. Oxford Research Encyclopedia of Politics. https://doi.org/10.1093/ acrefore/9780190228637.013.160

Soldatov, A. P. \& Bratanovsky, S. N. (2020). Public service: historical and legal research. Proceedings of the Academy of Management of the Ministry of Internal Affairs of Russia, 3(55), 129-139. 
Surmanidze, I. N. \& Kirillovykh, A. A. (2018). The legal regulation of guarantees provided for public (state) service in France, Switzerland and Austria. State Power and Local Government, (6), 51-55. Available: https://doi.org/10.18572/18131247-2018-6-51-55

USA. President of the United Stated. (2002). The President's Management Agenda. [Online]. Available: https://obamawhitehouse.archives.gov/sites/default/files/omb/assets/omb/budget/fy2002/mgmt.pdf

Van der Meer, F. M., Raadschelders, J. \& Toonen, T. (eds.). (2015). Comparative civil service systems in the 21st century. Berlin: Springer.

Wollmann, H. (2010). Evaluation in Public-sector reform: Toward a 'third wave' of evaluation? Sociological Research, (10), 9399. Available: https://www.isras.ru/files/File/Socis/2010-10/ Vollmann.pdf

Zhumagulov, M. I. (2016). The reformation and modernization of public service in the Republic of Kazakhstan and the Russian Federation. Society and law, 2, 79-86.

Zubov, M. G. (2017). Diplomatic service of the Kingdom of Norway. [Monograph]. Moscow: Aspekt-Press.

Alexander Georgievich Gurinovich. Doctor of Law, Professor of the Department of Administrative and Financial Law, Moscow State Institute of International Relations (MGIMO University) (Moscow, Russian Federation). https://orcid.org/0000-0002-9232-3960

Natalya Ivanovna Petrykina. $\mathrm{PhD}$ in Law, Associate Professor of the Department of Administrative and Financial Law, Moscow State Institute of International Relations (MGIMO University) (Moscow, Russian Federation). https://orcid.org/0000-0002-1865-0189 